\title{
Thainstone Business Park, Inverurie, Aberdeenshire
}

\author{
by H K Murray* and J C Murray*
}

with contributions by T Ballin ${ }^{1}$, A Heald ${ }^{2}$ and F Hunter ${ }^{2}$

*Murray Archaeological Services, Hill of Belnagoak, Ellon, Aberdeenshire AB41 7JN

${ }^{1}$ Lithic Research, Banknock Cottage, Denny, Stirlingshire FK6 5NA

${ }^{2}$ National Museums of Scotland, Department of Archaeology,

Chambers Street, Edinburgh EH2 
Published by the Society of Antiquaries of Scotland, www.socantscot.org.uk with Historic Scotland, www.historic-scotland.gov.uk and the Council for British Archaeology, www.britarch.ac.uk

Editor Debra Barrie

Produced by Archetype Information Technology Ltd, www.archetype-it.com

ISBN: 0903903903

ISSN: $1473-3803$

Requests for permission to reproduce material from a SAIR report should be sent to the Director of the Society of Antiquaries of Scotland, as well as to the author, illustrator, photographer or other copyright holder.

Copyright in any of the Scottish Archaeological Internet Reports series rests with the SAIR Consortium and the individual authors.

The maps are reproduced from Ordnance Survey material with the permission of Ordnance Survey on behalf of The Controller of Her Majesty's Stationery Office. CCrown copyright 2001. Any unauthorized reproduction infringes Crown copyright and may lead to prosecution or civil proceedings. Historic Scotland Licence No GD 03032G, 2002.

The consent does not extend to copying for general distribution, advertising or promotional purposes, the creation of new collective works or resale. 


\section{Contents}

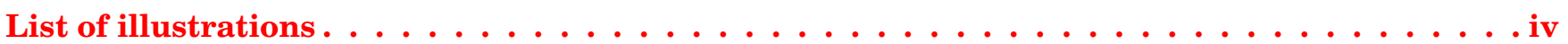

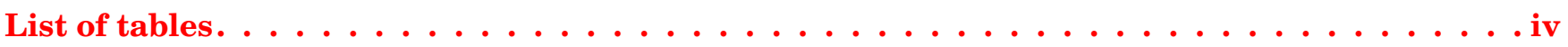

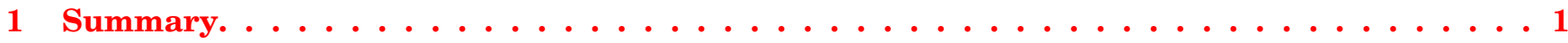

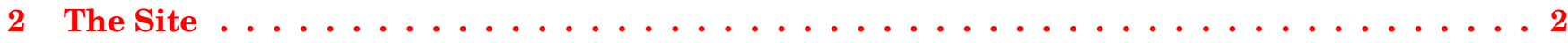

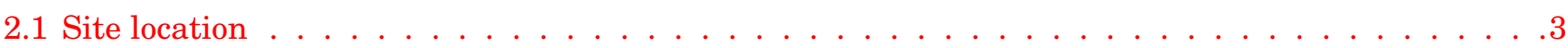

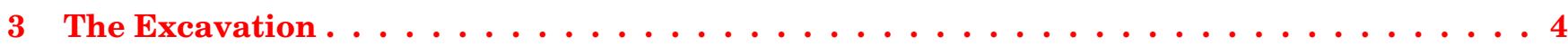

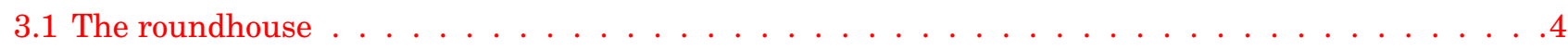

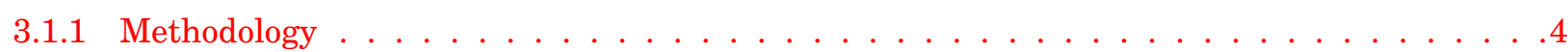

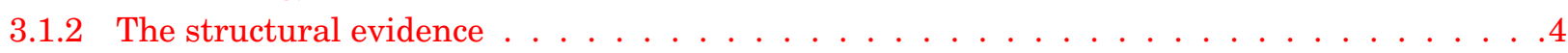

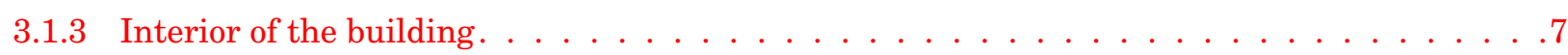

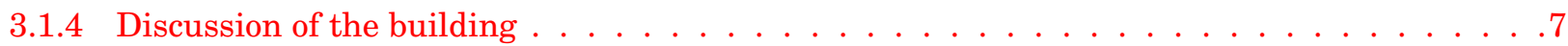

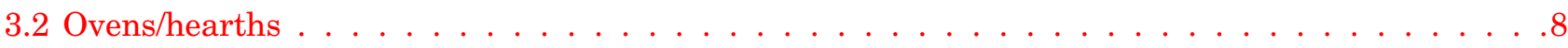

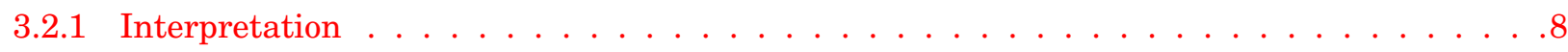

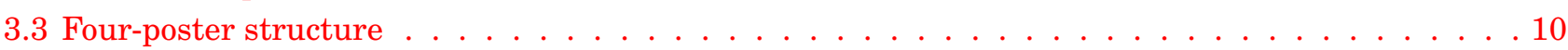

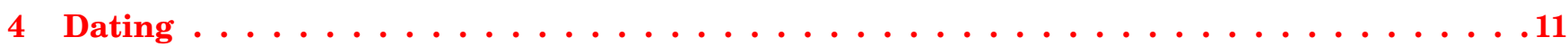

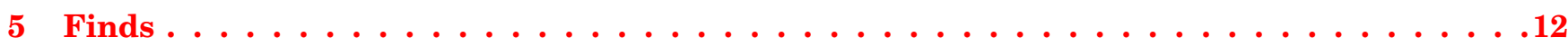

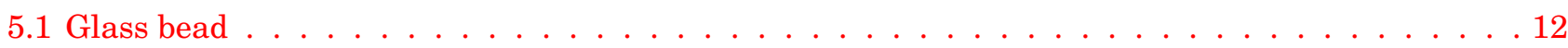

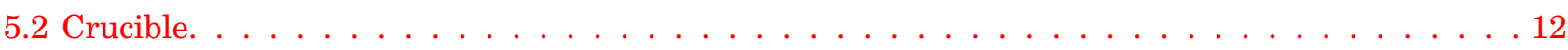

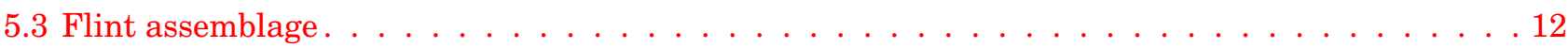

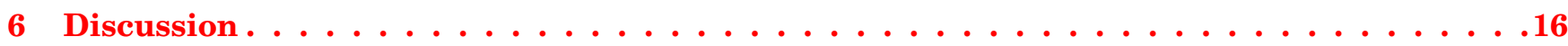

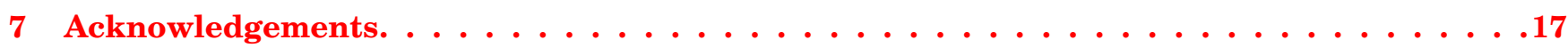

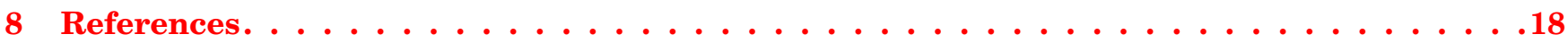




\section{List of illustrations}

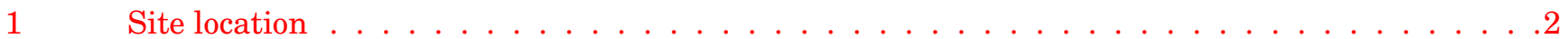

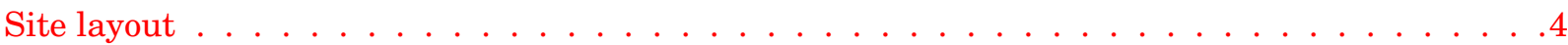

Location of primary and secondary post-pits in the roundhouse . . . . . . . . . . . . .5 General view of roundhouse looking south-east towards the entrance.

Painted markers show the position of the post-pits . . . . . . . . . . . . . . . . . . .

Section drawings of post-pits . . . . . . . . . . . . . . . . . . . . . 6

Post-pits 004 and 004 a, looking west . . . . . . . . . . . . . . . . . . . . . . . . .7

Ovens F023 and F051 . . . . . . . . . . . . . . . . . . . . . . . . . . . . . . . . . .9

Oven F023, looking north. White pegs mark post-holes . . . . . . . . . . . . . . . . .9

Oven F051, looking west. . . . . . . . . . . . . . . . . . . . . . . . . . . . . . . .9

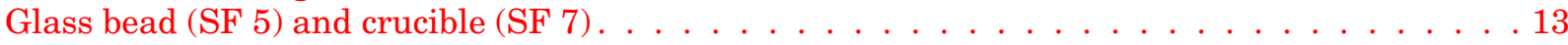

Glass bead (SF 5). . . . . . . . . . . . . . . . . . . . . . . . . . . . . . . . . 14

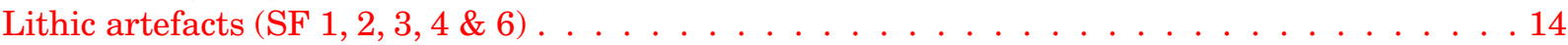

\section{List of tables}

Radiocarbon dates . . . . . . . . . . . . . . . . . . . . . 11 


\section{Summary}

Report on the excavation of a roundhouse and related structures dated by ${ }^{14} \mathrm{C}$ to the first-second century AD. Internal details and building repairs allow some assessment of the structure of the building. The site also provides a well-dated context for a Guido class 13 glass bead, a type more common in isolated finds. 


\section{The Site}

The site (NGR: NJ 773 181), which is adjacent to the Thainstone Agricultural Centre, is located $c 2 \mathrm{~km}$ south of Inverurie, Aberdeenshire, on land that once formed part of the policies of Thainstone House. As aerial photographs of the site showed faint traces of a possible enclosure $c 50 \mathrm{~m}$ in diameter centred at NJ 77331814 (Aberdeenshire Council Sites and Monuments Record Site No NJ71NE0151), an archaeological evaluation (illus 1, Trenches 1-9) was carried out on the site in November 2002, prior to its development as a business park (Murray 2002). The evaluation showed little surviving archaeological material but the presence of a flint scraper (SF 1) and certain areas of burning at the south-east end of the site led to a watching brief being maintained during the soil strip in two areas. During the watching brief it became clear that some archaeological deposits had survived in the area of the burning. This part of the site was then excavated by hand.

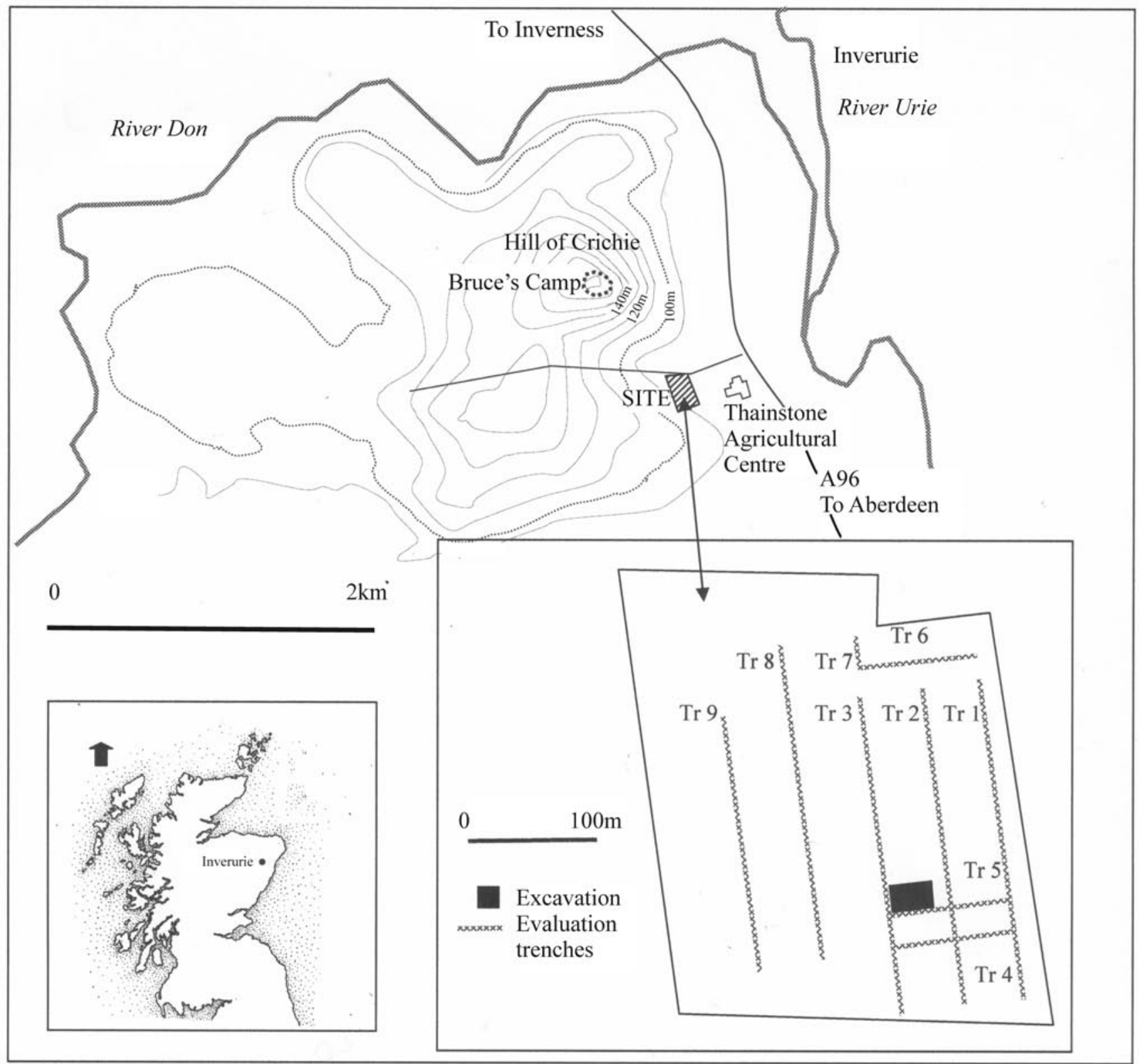

Illus 1 Site location 


\subsection{Site location}

The site is situated on the east-facing slope of an area of relatively high ground (illus 1 : see the $100 \mathrm{~m}$ contour) which stands within and dominates a loop of the River Don, beside its confluence with the River Urie. At the top of the high ground, above the present site, there is an enclosed settlement or fort (Bruce's Camp), possibly of Iron Age date. A major routeway beside the Don and Urie may have existed from at least the
Neolithic, with a concentration of sites along the river valleys (Shepherd 1986, 11-12). The same route has often been attributed as the line of march between the Roman temporary camps at Kintore and Durno, both generally linked with the Agricolan campaign of $83 \mathrm{AD}$ (Breeze 1996, 45-6, illus 29). It was subsequently used as the medieval road from Aberdeen to the north, and is now the line of the A96. The area on which the Thainstone site lies overlooks this routeway and potentially controls the river crossing. 


\section{The Excavation}

An area $20 \times 30 \mathrm{~m}$ was excavated (illus 1 ; illus 2). A number of features cut into the natural boulder clay were revealed directly below $300-350 \mathrm{~mm}$ of topsoil. The field had been intensively cultivated in the years prior to excavation. Ploughing and disturbance by field drainage systems had destroyed stratigraphic relationships across the site, making it impossible to subdivide the features into phases. As a result, the features are described in the following structural groups: the roundhouse, the two hearths or ovens and the four-post structure.

\subsection{The roundhouse}

\subsubsection{Methodology}

Discussion of the building relies on the earthfast elements of the structure, particularly the ring of post-pits which would have held roof supports. In order to maximize possible structural evidence, all post-pits on or near the line of the ring were sectioned and drawn on radial lines from the centre of the ring, in the direction of structural stress during and after construction (based on reconstruction research in progress; Murray, in preparation).

The only exceptions were those post-pits that were intercut; these were sectioned across both pits to attempt to reveal their relationship.

The lack of horizontal stratigraphy means that some of the observed features may be earlier or later than the roundhouse although there was nothing in the fills or artefactual evidence to suggest that this was the case. It does, however, mean that interpretation of isolated post-holes can only be tentative.

\subsubsection{The structural evidence}

A number of post-pits, interpreted as the main roof supports, formed a ring approximately $7 \mathrm{~m}$ in diameter (illus 3; illus 4). Analysis suggests two possible episodes of building or repair.

A series of seven of the post-pits $(003,004 \mathrm{~A}$, 007, 038, 036, $031 \& 027$ ) around the west, north and east sides of the ring were distinctive. The pits were $470-550 \mathrm{~mm}$ in diameter, with surviving depths of between 250 and $450 \mathrm{~mm}$ (illus 5). Clear post-shadows, diameter $200-280 \mathrm{~mm}$, survived in two of the post-pits $(003 \& 004)$. Two other possible post-shadows were in the range of $150-300 \mathrm{~mm}$ in diameter. With the exception of Post-pit 027, which appeared to have been reused, all the post-pits in the series had convincing stone packing on the side

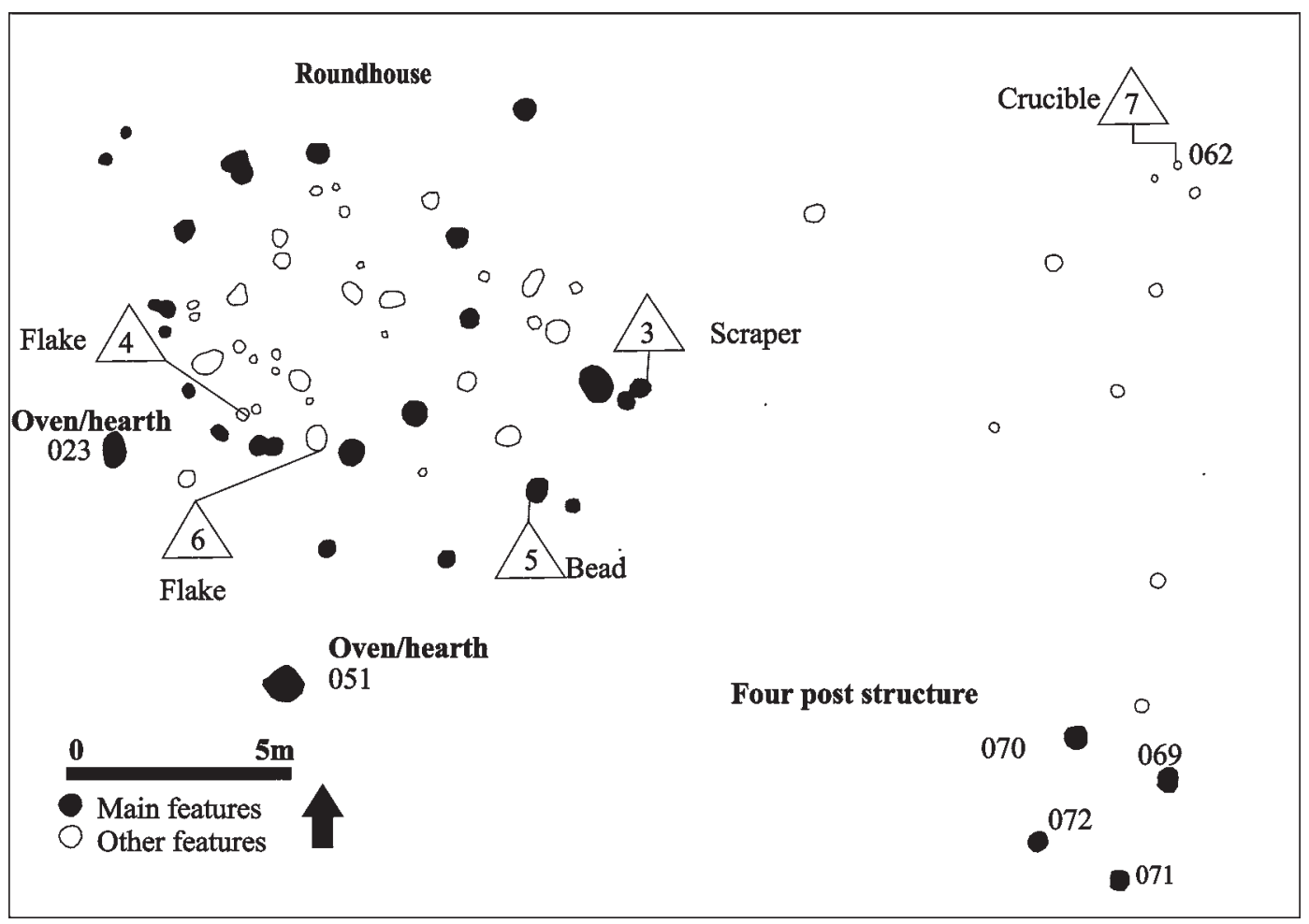

Illus 2 Site layout 


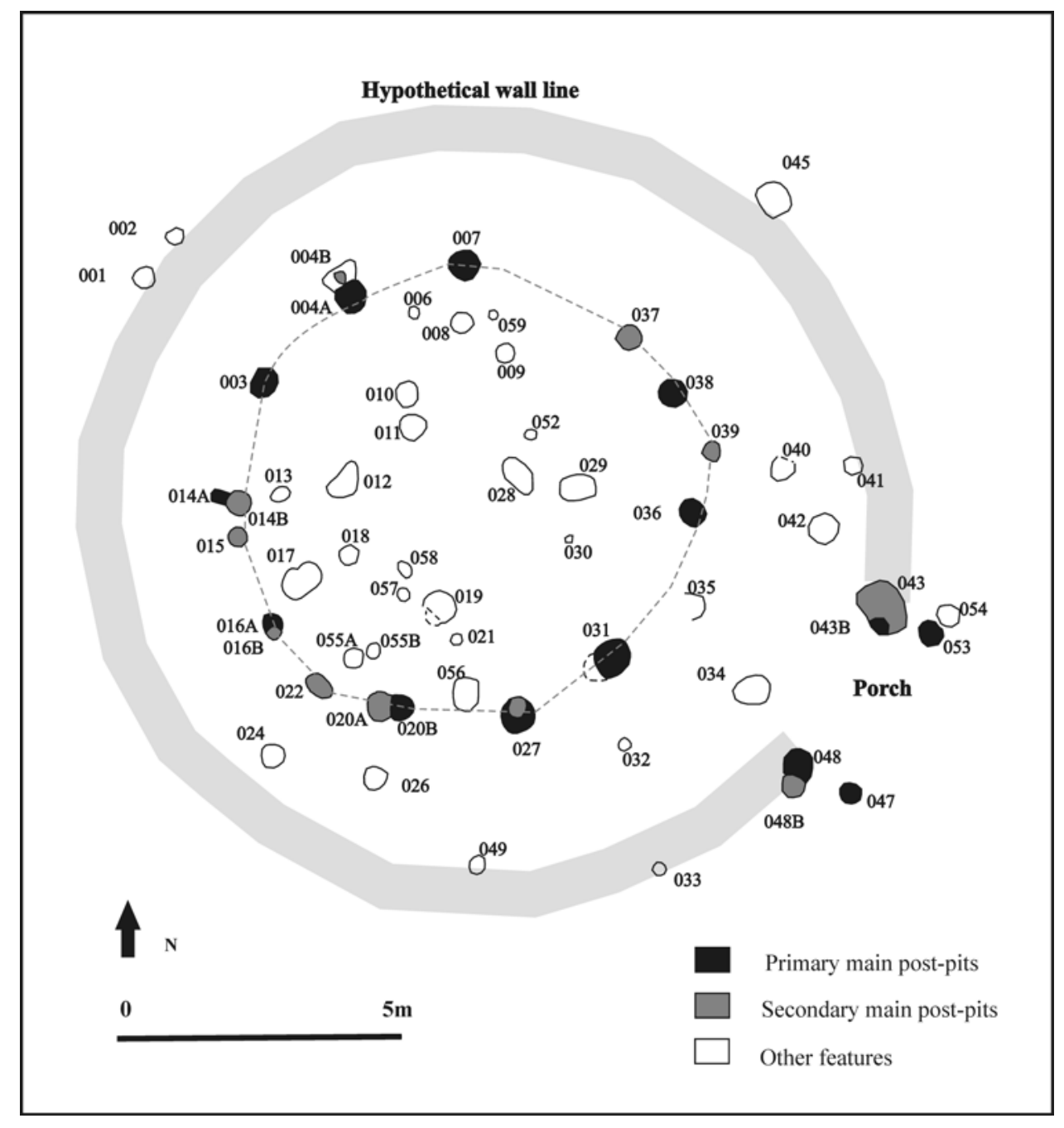

Illus 3 Location of primary and secondary post-pits in the roundhouse

of the pit which faced the centre of the building. Post 036 , to the north side of the entrance, had additional packing stones on its north side.

These post-pits were $c 1.80 \mathrm{~m}$, or roughly two paces, apart (centres). A gap between Post-pits 007 and 038

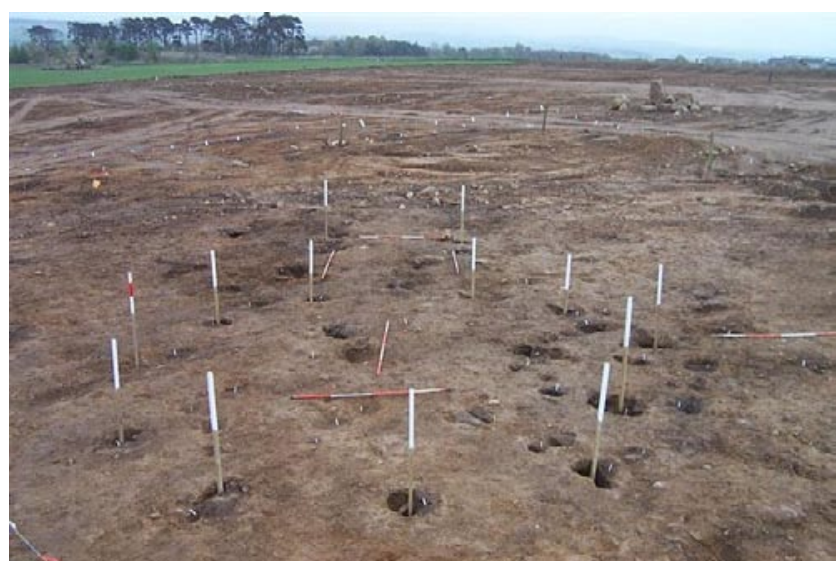

Illus 4 General view of roundhouse looking southeast towards the entrance. Painted markers show the position of the post-pits appears to have been the result of disturbance by modern field drainage. A spacing of $2.50 \mathrm{~m}$ between Post-pits 031 and 036 is discussed below. For two reasons these features are regarded as the primary stage of building. Firstly, there is evidence of later repair as the post-pit of one of the posts (004A) had been cut by the pit of a later, angled buttressing post (004B) (illus 5; illus 6), and two other post-pits (027 $\& 031$ ) appeared to have been reused. Secondly, it is only this set of large post-pits which have the stone packing towards the centre of the building. This would have stopped the base of the posts shifting inwards against an outward pressure on the tops of the posts, a situation which is most likely to have arisen during the initial positioning and construction of the roof. Once the roof was in position, it would have been relatively stable, unless damaged by external influences (based on reconstruction research in progress; Murray, in preparation).

The pattern of posts at $c 1.80$-m intervals continues around the south-west part of the main post ring but in this area two of the posts (016A and 020B) had been replaced (by 016B and 020A) and, as noted above, Posts 027 and 031 may also have been replaced by new posts in the original holes. Post 014B also cuts an 


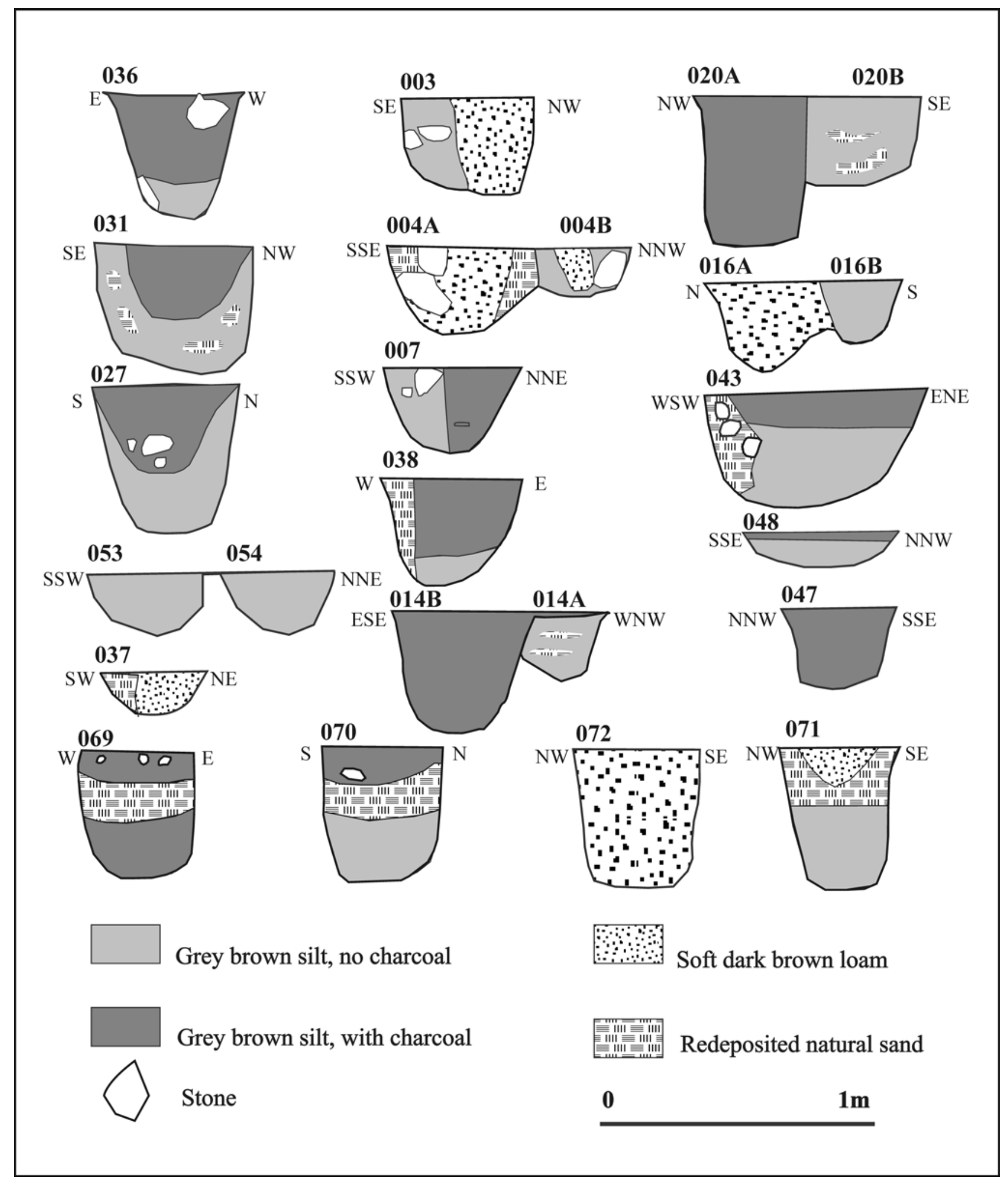

Illus 5 Section drawings of post-pits

earlier, smaller post-pit (014A) but this is less clearly a replacement as Post 014A was $c 300 \mathrm{~mm}$ outside the apparent line of the post ring.

A number of other relatively shallow post-pits (037, 039, $022 \& 015)$, on or near the line of the ring of roof supports, may also have been repairs or secondary supports but the lack of horizontal stratigraphy make this impossible to prove and it is equally possible that they represent the foundations of internal screens or partitions.

The evidence for the line of the outer wall is tenuous. It may be indicated by a number of postpits (001, 002, 045, 041, 043, 048, 033 and, possibly, 049) found around the perimeter of the structure and roughly equidistant from the post ring. These are the basis of the hypothetical wall line shown in 


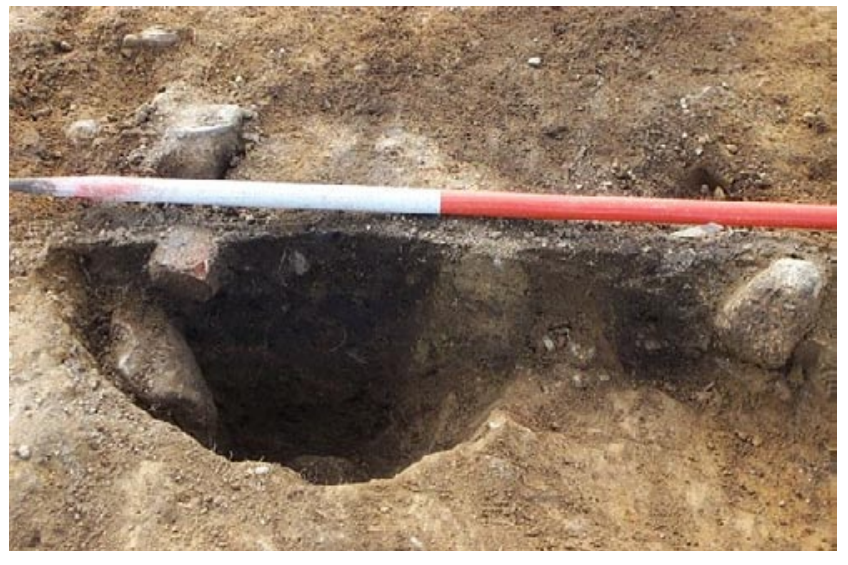

Illus 6 Post-pits 004 and 004a, looking west

the plan (illus 3 ) and would suggest a building of around $12-12.5 \mathrm{~m}$ in diameter.

Two of the post-pits on this outer line ( $043 \&$ 048) coincide with the gap of $2.50 \mathrm{~m}$ between Posts 031 and 036 of the post ring and may be interpreted as the entrance. A corresponding set of outlying postholes $(053 / 054 \& 047)$ may represent a porch (see further below). Both Posts 043 and 048 appear to have been replaced. This possible entrance lies in the south-east quadrant of the building.

\subsubsection{Interior of the building}

North-west quadrant The area within the post ring and opposite the entrance was characterized by a number of irregular, rather saucer-shaped shallow hollows $(006,010,011,012)$ up to $50-100 \mathrm{~mm}$ deep, which were filled with sandy silt; context 012 was around an undisturbed natural stone. Features 008, 009 and 013 may have been small post-holes. No comparable features were observed between the post ring and the possible wall line.

South-west quadrant There appeared to have been a structure in this area at some point in the building's existence. The evidence was more concentrated within the line of the post ring but two features (contexts $024 \& 026$ ) between the ring and the hypothetical line of the outer wall have been included as possibly related. A sub-rectangular area was bounded by Post-pits 017, 018, 019, 056 and 026, with related Post-holes 055 and 058 and Hollows 057,021 and 024 . The post-pits were fairly substantial (330-550 mm diameter and $140-250 \mathrm{~mm}$ deep), with a post shadow $250 \mathrm{~mm}$ in diameter in Post-pit 017 , and were capable of load bearing. However, it is unlikely that Post-pits 017 and 056 had held roof supports as they were well within the ring line. Charcoal identified as birch (larger roundwood) and hazel (twig) (Hastie 2005) in the top of Post-pit 018 might suggest the use of wattle or of a structure incorporating light timber. Two flint flakes (SF 4 and 6) were found in this area.
North-east quadrant This area was a fairly clear apart from a small pit or shallow post-pit (029) and a very small patch of burning and charcoal (028). It would be tempting to consider context 028 as the remains of a hearth but it was very disturbed by ploughing and topsoil removal and should be treated with caution. A line of three small, shallow post-holes $(030,052 \& 059)$ with very similar grey, silty fill extended across the north-east and southeast quadrants; they may be related to the building but the fill was unlike that of the other features.

South-east quadrant and the entrance If the identification of Post-pits 043 and 048 as the entrance is correct, the area between the entrance and the post ring would be the line of movement, or passage, either to the centre of the building, or to the area between the post ring and the outer wall. Within this area there were two irregular depressions (034 \& 035), 80-120mm deep, which appear to be the result of erosion/wear rather than having been cut. Pits 040 and 042 to the northern side of the passage were both between 460 and $550 \mathrm{~mm}$ in diameter and 200-300 $\mathrm{mm}$ deep and may indicate the position of a partition or other structure in this area. A flint scraper (SF 3) was found in Post-pit 054, and part of a glass bead (SF 5) was found in Post-pit 048 on either side of the entrance.

\subsubsection{Discussion of the building}

Although only earthfast elements survived, some conclusions may be suggested concerning the possible structure of the building. Firstly, there are a number of points which support the common reconstruction of these roundhouses as having the main weight of the roof carried on a ring beam, rather than on the external wall.

The size and depth of the post-pits and the size of posts, indicated by post shadows, suggest a considerable weight-bearing capacity. The regularity of the spacing of the primary posts suggests that the roof weight was shared equally between them, and the packing of the primary post-pits on their inner faces suggests that they were being given support against stress from inside. All of these features would be compatible with individual posts supporting individual rafters, but the details of the repairs indicate that the posts were linked, probably by a ring beam. The repairs on the south-west side suggest that, at some time in the life of the building, a whole section of the roof support system needed propping and appears to have been repaired while the rest remained intact. It is important not to be too quick to suggest a complete rebuild as it is quite easy to prop sections of a ring beam between the main posts (on the same principal as using a modern Acro-prop); Post-pits 015 and 022 may have been such props. When the roof weight had been transferred, then the original main post could have been removed and a substitute post put in, or even the 
same post replaced and re-packed (as in, perhaps, contexts 014, 016, 020). The fact that the buttressed post (004) was on the opposite side suggests that instability on one side of the roof could affect the other side, a situation that is more probable if the posts had been linked by a ring beam. As many of the prevailing winds in the area come from the west, this seems the most probable cause of the instability, even though in general the aerodynamics of a round building enable it to withstand quite strong winds (Murray, in preparation).

Evidence for the line of the outer wall is slight but suggests a building with a diameter of about $12-12.5 \mathrm{~m}$. This is slightly greater than the $10 \mathrm{~m}$ diameter which would be achieved by applying the optimum ratio between the post-ring and outer wall as suggested previously (Hill 1984). However, it agrees well with Pope's suggested modification of this ratio (1:0.615) based on a large sample of excavated roundhouses (Pope 2003, 107), which would suggest that the outer wall of this structure might have had a diameter of some $11-12 \mathrm{~m}$. The wall is unlikely to have been of stone or clay as at least some spread of wall debris could have been expected to be present in the tops of the earthfast features. A turf wall, or a shallow-based wattle wall, are possible. It should be stressed that the posts identified as possibly being on the wall line, may in reality have been on either the inner or outer face of that wall.

The entrance in the south-east quadrant of the Thainstone roundhouse follows the most common orientation of roundhouse entrances to the east or south-east and locally can be paralleled by the trend in the larger group of earlier Iron Age structures excavated nearby at Kintore (M Cook, pers comm). Whether such orientation should be interpreted functionally in terms of light within the structure, or ritually in terms of the cosmology of the building (for example Oswald 1997; Parker Pearson \& Sharples 1999), is considered to be outwith the scope of this paper, which is based on a single excavated example.

Posts 047 and 053/054 are interpreted as having held the outer lintel of a porch. This is perhaps confirmed as they coincide with the slightly wider spacing between roof Posts 031 and 036 and with the patches of worn ground within the supposed passage area $(034,035)$.

The need for a porch was probably twofold: it would provide some weather protection but, perhaps more essentially, if the outer wall was relatively low, the porch lintel could be higher than the wall top, supporting the outer edge of the roof at the entrance. If this assumption is correct, the repaired Posts 048/048B and 043/043B, may have held the door.

On this basis it may be conjectured that, if the main part of the roof extended from the apex of the building to the wall, with the weight carried on a ring beam at a height of $c 3 \mathrm{~m}$, then with an average $45^{\circ}$ pitch for thatch, this would give a central height of $c 6.5 \mathrm{~m}$, allowing a shallower pitch from the ring to the porch lintel. The height of the main wall below this could have been in the range of $0.5 \mathrm{~m}$ if the building had a diameter of $12 \mathrm{~m}$, and up to $1.5 \mathrm{~m}$ if the building had a diameter of $10 \mathrm{~m}$.

The lack of floor deposits limits interpretation of the function or use of the building but the evidence does suggest that there was an area of considerable activity in the north-west quadrant, which had caused some erosion even in the top of the natural subsoil. This is perhaps unsurprising as this quadrant opposite the door receives good light levels through much of the day, even in winter when more tasks would be undertaken inside.

Some of the roundhouses excavated at Kintore, Aberdeenshire, had erosional hollows, which tended to be deepest, or only present, in the north or northeast sector; however, none of these are contemporary with the Thainstone example (M Cook, pers comm). The same pattern has been observed in Iron Age roundhouses excavated at Birnie, Moray (Hunter 2002a, 9).

There also appears to have been some sort of structure in the south-west quadrant of the Thainstone building, possibly a bench or bed. A similarly situated feature in Cladh Hallan House 401 (Marshall et al 1999, 18, fig 8) was interpreted as the possible setting of a vertical loom, but there is no evidence for such a specific identification at Thainstone.

\subsection{Ovens/hearths}

To the south-west of the roundhouse, there were two small hearths or ovens (023 \& 051) (illus 7). It is not possible to determine if these were contemporary with the roundhouse, or with each other, although their structural similarity suggests that they were intended for the same function. Both were roughly ovoid, $1.04-1.25 \mathrm{~m}$ long and $0.70-0.80 \mathrm{~m}$ wide, being divided into a pit at one end, some $250-370 \mathrm{~mm}$ deep, and a higher area of cobble flooring at the other end. In both features there were some stones apparently lining the sides of the pit. Feature 023 (illus 8) also had a few small stake-holes, diameter $20 \mathrm{~mm}$, around the upper edge on the south and west sides. There was a small quantity of charcoal in the base of Feature 051 (illus 9), but no concentration of charcoal, or any appearance of heat-affected soil occurred in either feature. However, in both instances, the pit was partially filled with heatcracked stones (up to $250 \times 200 \mathrm{~mm}$ ), the remaining fill appearing to be silt accumulated in the pits after the deposition of these stones.

\subsubsection{Interpretation}

Heat-cracked stones as found in these features can be produced by cooking with hot stones in water in the manner of a burnt mound. However, this is unlikely as the features lacked the quantities of either stone or charcoal produced by cooking this 

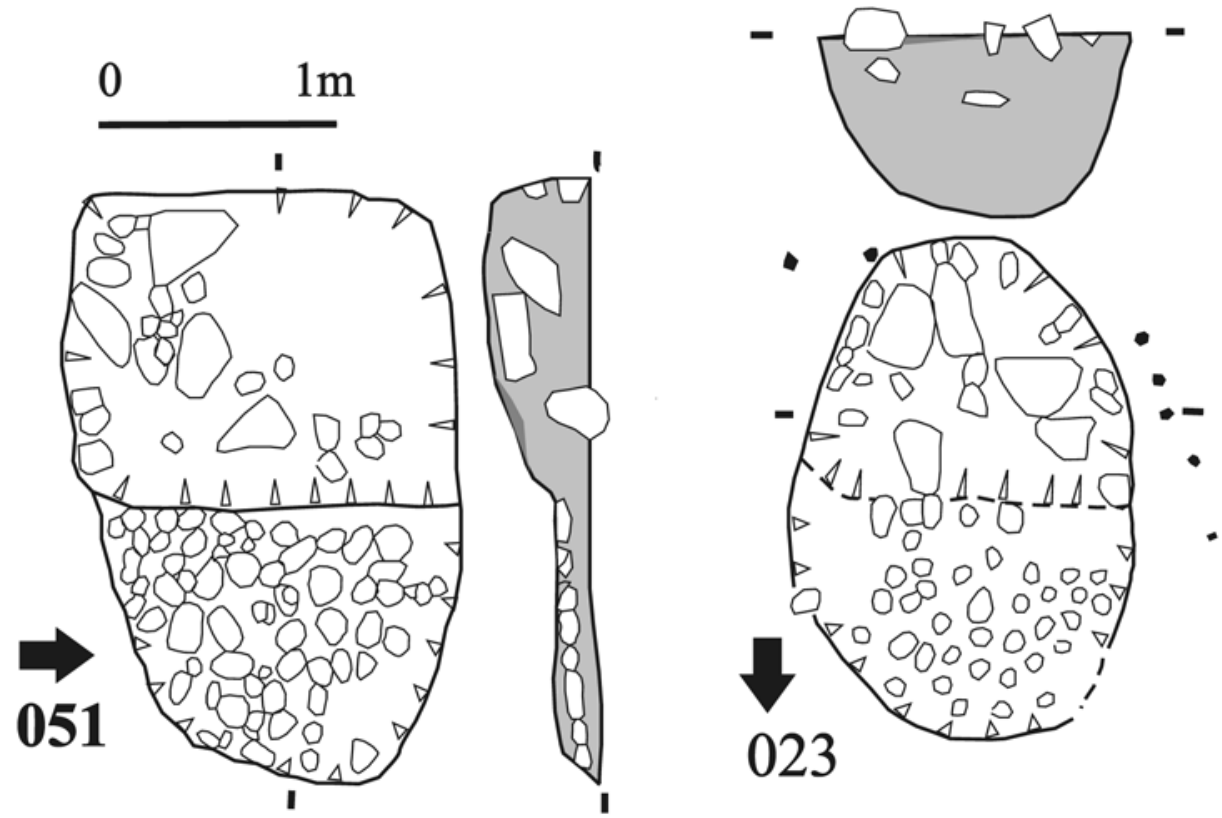

Grey brown silt, no charcoal

Grey brown silt with some charcoal

1 Post-hole

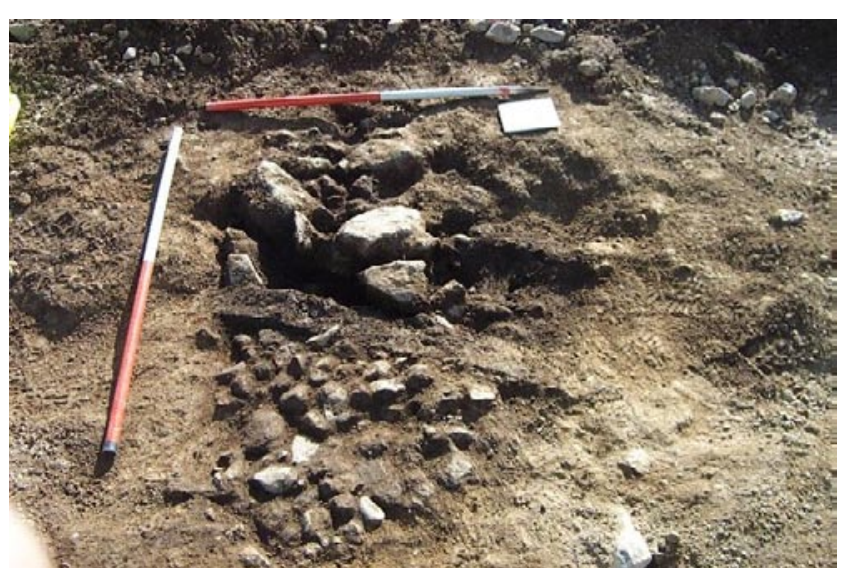

Illus 8 Oven F023, looking north. White pegs mark post-holes

way, even on a small scale. It is more probable that the heat-cracked stones derived from the collapsed superstructure of an oven or hearth built on the cobbles. The function of the pit in each hearth is not clear as there was no evidence of a rake out of burnt material; one possibility could be that they had held small bellows.

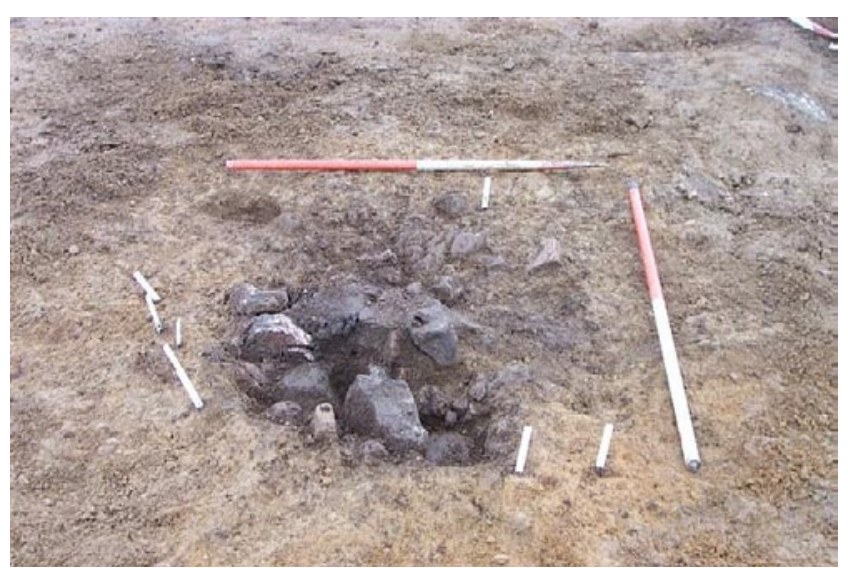

Illus 9 Oven F051, looking west

It is worth considering if these could have been industrial hearths. The crucible fragment (SF 7), although from the other side of the site, shows that metalworking took place in the vicinity, and one possible explanation of these features would be as small bronzeworking hearths. Small-scale bronzeworking does not produce large quantities of debris 
and experimental casting shows that the ground below is often not visibly heat-affected. The identification of these hearths with metalworking may perhaps be supported by the excavation at Birnie, Moray, of part of a tuyere, or bellows shield, in a linear scoop (Hunter 2003, 13). On the same site, a clay ingot-mould has been found in the central hearth in one of the roundhouses (F Hunter, pers comm), which may indicate that small-scale bronzeworking could even have utilized domestic hearths.

However, analysis of a sample of the infill of Feature 023 lacked any evidence of industrial debris: 'The palaeoenvironmental remains present were extremely sparse including one small fish bone vertebrate, occasional small fragments of poorly preserved mammal bone ( $<1 \mathrm{~mm}$ in size), fragments of wood charcoal and one poorly preserved oat grain' (Hastie 2005). This very small amount of material may have derived from general occupation debris washed into the oven pit after it fell into disuse. However, the lack of industrial material, which might equally have been expected to have been in the surrounding yard area, suggests that both Features 023 and 051 may have been predominantly, if not exclusively, used for domestic food preparation.

If the identification of these external ovens as domestic is valid, and if they were indeed contemporary with the roundhouse, it has some implication in considering the functions that took place within a 'house' and may suggest caution in automatically assuming all houses had internal hearths or where such hearths exist that they were primarily for cooking.

\subsection{Four-post structure}

To the south-east of the roundhouse there was a group of four post-pits (illus 2) set at the corners of a rectangle, with sides of $2.25-2.45 \mathrm{~m}$. The diagonals (to centres) were both $3.35 \mathrm{~m}$. The post-pits, which were all straight-sided and flat-bottomed, ranged in diameter from 400 to $500 \mathrm{~mm}$ and in depth from 450 to $520 \mathrm{~mm}$. Three of them $(069,070,071)$ had a very similar sequence of fills - a lower fill of silt sealed by $100-150 \mathrm{~mm}$ of silt lensed with redeposited natural sand - suggestive of the posts having been removed, followed by a gradual silting up. This appeared to have sunk down before the accumulation of charcoal-rich layers which were very similar to those in the upper fills of the roundhouse postpits. The fill of the fourth pit (072) was of uniformly loose soft brown silt.

Similar four-post features are generally regarded as raised granaries or stores (Gent 1983, 245-51). There was no evidence for the function of the Thainstone structure; indeed, the fact that it appeared to have been dismantled would mitigate against the presence of any remnant of stored grain or other goods even if the survival of occupation levels on the site had been better. It is slightly smaller than most of the rather earlier four-post structures from Kintore, Aberdeenshire, the majority of which ranged between 2.5 and $3 \mathrm{sq} \mathrm{m}$ (M Cook, pers comm). However, it is within the range recorded by Gent (see Gent 1983, 245) and is similar to other examples such as at Lower Greenyards, Stirling (Rideout 1996, 232 ), where there were two, approximately $1.8 \mathrm{sq} \mathrm{m}$ and $2.1 \mathrm{sq} \mathrm{m}$, respectively, $6-7 \mathrm{~m}$ from a roundhouse.

The appearance of the posts having been removed in the Thainstone example suggests that it may have been in use in the early stages of the settlement and then moved or replaced. It is not possible to be categoric that it was in use when the roundhouse was originally built, but its proximity makes it possible. The radiocarbon date from charcoal sunk into the top fill of one of the posts suggests that the four-post structure was out of use by the third century AD. 


\section{$4 \quad$ Dating}

Four radiocarbon dates (Table 1) were analysed for the site. Three of these were from main postspits of the post ring in the roundhouse (Post-pits 004A, 014B \& 020A). The building had burnt down, charring the posts but not creating burnt post-pipes. When each of the unburnt post bases had rotted, burnt material from the post, and potentially from other burnt structural timbers such as roofing, had sunk into the top fill of the post-pits. Each of the three samples was taken from below the surface of this top fill in order to increase the likelihood that the charcoal derived from the post itself. Singleentity samples were taken from each context as it was felt that the three samples together should give a range of dates derived from a number of the structural timbers, or possibly from incidental timber such as firewood that was in the building when it burnt down.

The samples give a calibrated range of dates which extend from the late first century $\mathrm{BC}$ to the beginning of the third century $\mathrm{AD}$, and suggest that the building was probably constructed and used in the first-second centuries AD. It is perhaps significant that the sample from Post-pit 020A gives a slightly later range of dates than the other two samples, as this was clearly a replacement post (see above).

Unfortunately, the charcoal samples were not identified to species prior to analysis. Identifica- tion of wood from the same sample contexts shows a predominance of oak, probably from the main structural timbers, with some birch and hazel, which may have derived from fallen wall or roof material. If split timber had been used, there is of course a possibility that a mixture of core and outer timber was dated, giving a spread of dates. However, although in the absence of carbonized post-pipes it is impossible to be certain, the four examples where clear post shadows survived, all appeared to have been round timbers $c 150-300 \mathrm{~mm}$ in diameter.

The fourth radiocarbon sample was from the charcoal-rich upper fill of Post-pit 071, the southeastern post of the four-post structure. It yielded a date between the later first and early third centuries $\mathrm{AD}$, comparable to the date from the replacement Post-pit 020A in the roundhouse. It is suggested that this may have derived from charcoal from timber associated with the destruction or use of the roundhouse, sunken in over the apparently dismantled and silted up post-pit of the four-post structure. It does not directly date the construction or use of the four-post structure but does indicate that it was out of use by the time the roundhouse was destroyed. No samples suitable for dating were recovered from the lower fills of any of the four post-pits.

The finds, while not closely datable, are consistent with a floruit in the first-second century AD.

Table 1 Radiocarbon dates

\begin{tabular}{|c|c|c|c|c|c|}
\hline \multirow[t]{2}{*}{ Lab code } & \multirow[t]{2}{*}{ Sample material } & \multirow[t]{2}{*}{ Years BP } & \multirow[t]{2}{*}{$\delta^{13} \mathbf{C} \%$} & \multicolumn{2}{|c|}{ Calibrated dates } \\
\hline & & & & 1-sigma & 2-sigma \\
\hline Beta-181169 & $\begin{array}{l}\text { Charcoal from top of post shadow } \\
\text { (4/1) of main primary Post F4A }\end{array}$ & $1940 \pm 40$ & -25.0 & AD $30-100$ & 30 BC-AD 130 \\
\hline Beta-181170 & $\begin{array}{l}\text { Charcoal from secondary (?) } \\
\text { Post-pit F14B }\end{array}$ & $1960 \pm 40$ & -26.0 & $\mathrm{AD} 10-80$ & $40 \mathrm{BC}-\mathrm{AD} 120$ \\
\hline Beta-181171 & $\begin{array}{l}\text { Charcoal from secondary (?) } \\
\text { Post-pit F20A }\end{array}$ & $1830 \pm 40$ & -25.1 & $\mathrm{AD} 130-240$ & $\mathrm{AD} 90-260$ \\
\hline Beta-181172 & $\begin{array}{l}\text { Charcoal from F71/1, top fill } \\
\text { of post-pit of four-poster }\end{array}$ & $1870 \pm 40$ & -25.4 & AD 90-220 & $\mathrm{AD} 60-240$ \\
\hline
\end{tabular}




\section{$5 \quad$ Finds}

With the exception of two thumbnail scrapers (SF 1 \& 2 ), which were both from the topsoil at some distance from the roundhouse, all the finds were from the fill of post-pits (illus 2). There are two possible points of such deposition. Objects can be incorporated, accidentally or deliberately, during the backfilling of a post-pit around the post, in which case they derive from contemporary or earlier occupation material cut by or surrounding the post-pit. Alternatively, material can accumulate in the hollow created as the backfilled material compacts, in which case it derives from contemporary occupation levels which have been otherwise ploughed away. The general lack of evidence of earlier activity around the roundhouse suggests that the small finds are likely to be from contemporary occupation.

Two of the finds - a scraper (SF 3) and half a glass bead (SF 5) - were found in post-pits on the outside of the porch. It is intriguing to speculate that these might be foundation offerings; however, there is evidence of the replacement of posts at the entrance, so it is probably safer to interpret them as incidental lost objects.

\subsection{Glass bead by Fraser Hunter}

SF 5 Half a glass bead of Guido class 13 (Guido 1978, 85-7). Translucent clear body with opaque yellow spiral trails; the intact spiral is anticlockwise. Hexagonal in shape, caused by squashing the triangular corners when marvering the spirals into the body. Glass very bubbly, external surfaces all slightly worn. D $15.5 \mathrm{~mm}, \mathrm{H} 10.5 \mathrm{~mm}$, cylindrical perforation D4 mm. Context: Feature 048/1 (illus 10; illus 11).

The Thainstone bead falls within the distribution of type, which concentrates strongly between the Moray Firth and the Mounth (Guido 1978, fig 34). Other recent finds come from Birnie, Moray (DES 2000, 59) and Dun Bharabhat, Lewis (Harding \& Dixon 2000, 28-9), the latter adding to the evidence of contacts with other areas. Laing identified the type as Pictish (Laing 1974, 197-8) on the basis of a fragment from the ninth-century hoard from Croy, Inverness-shire (Grieg 1940, 193-4), but this undoubtedly represents expedient reuse of a decorative item, presumably intended as an inset for metalwork. Guido suggests a first- to second-century AD date for the type (Guido 1978, 86-7), which the Thainstone dates would support. The Bharabhat example comes from secondary occupation deposits with two associated radiocarbon dates (Harding \& Dixon 2000, 26-7); statistical testing indicates these may be combined to give a 2-sigma range of $170 \mathrm{BC}$ to $\mathrm{AD} 30$. This suggests the type starts rather earlier than Guido allowed; her dating of northern material was rather conservative, influenced as it was by ideas of diffusionism. Equally, the Bharabhat sequence has few dates, but it does open the possibility that the origins of the type lie in the first or second century BC, running to the second century AD. Henderson has recently suggested that the kindred Guido class 14 beads could have origins in the first century BC (Henderson 1994).

\subsection{Crucible by Andrew Heald}

SF 7 Crucible fragment. Rim and body sherd, the rim inturned at one end. Exterior and interior have no signs of vitrification. XRF analysis revealed traces of copper and tin, indicating that the vessel was associated with bronzeworking. Although fragmentary, the crucible appears to be of the open triangular form. This type was used from the first millennium $\mathrm{BC}$ to the mid- to late first millennium $\mathrm{AD}$ and is the most common form recovered from Scottish Iron Age sites. The Thainstone crucible is not from an independently dated feature, but is most likely to be contemporary with the other Late Iron Age activity on the site. There are few crucibles of this date from northeast Scotland, and it seems bronzeworking was a craft restricted to more important sites. For example, similar crucibles were recovered from Birnie, Moray, argued to be a status site from the discovery of two Roman coin hoards and a range of other prestige goods, including Roman brooches (DES 2002, 81; Hunter 2002). The Thainstone and Birnie crucibles should be seen as part of the goods and expertise circulating at this high level of society. $\mathrm{H}$ $34 \mathrm{~mm}, \mathrm{~W} 31 \mathrm{~mm}$, T 5mm. Context: Feature 062 (illus 10).

\subsection{Flint assemblage by Torben Ballin}

In total, five flint artefacts were recovered from the site: two thumbnail scrapers from areas outside the main building (SF $1 \& 2$ ), and three from likely or certain post-holes within it (SF $3 \& 6$ ) or from the immediate surroundings of post-holes (SF 4). SF 2 has a slight sheen or gloss, most probably from deposition in a sandy matrix (Donahue \& Burroni 2004), whereas the remaining pieces appear to be fresh. None of the pieces is burnt, and the abraded cortex of CAT 1-4 suggests procurement from a pebble source.

SF 1 Thumbnail end-scraper on primary bipolar flake or bipolar core, fine-grained light olive-green flint $(28 \times 27 \times$ $12 \mathrm{~mm})$. SF 1 has one fully corticated face and one uncorticated face. The end opposite the scraper-edge is a typical bipolar crushed terminal, or knapping seam. The piece is approximately circular, and at the working end it has a regular convex, steep $\left(82^{\circ}\right)$ scraper-edge. This retouch also covers most of the two lateral sides. Most likely, the modi- 

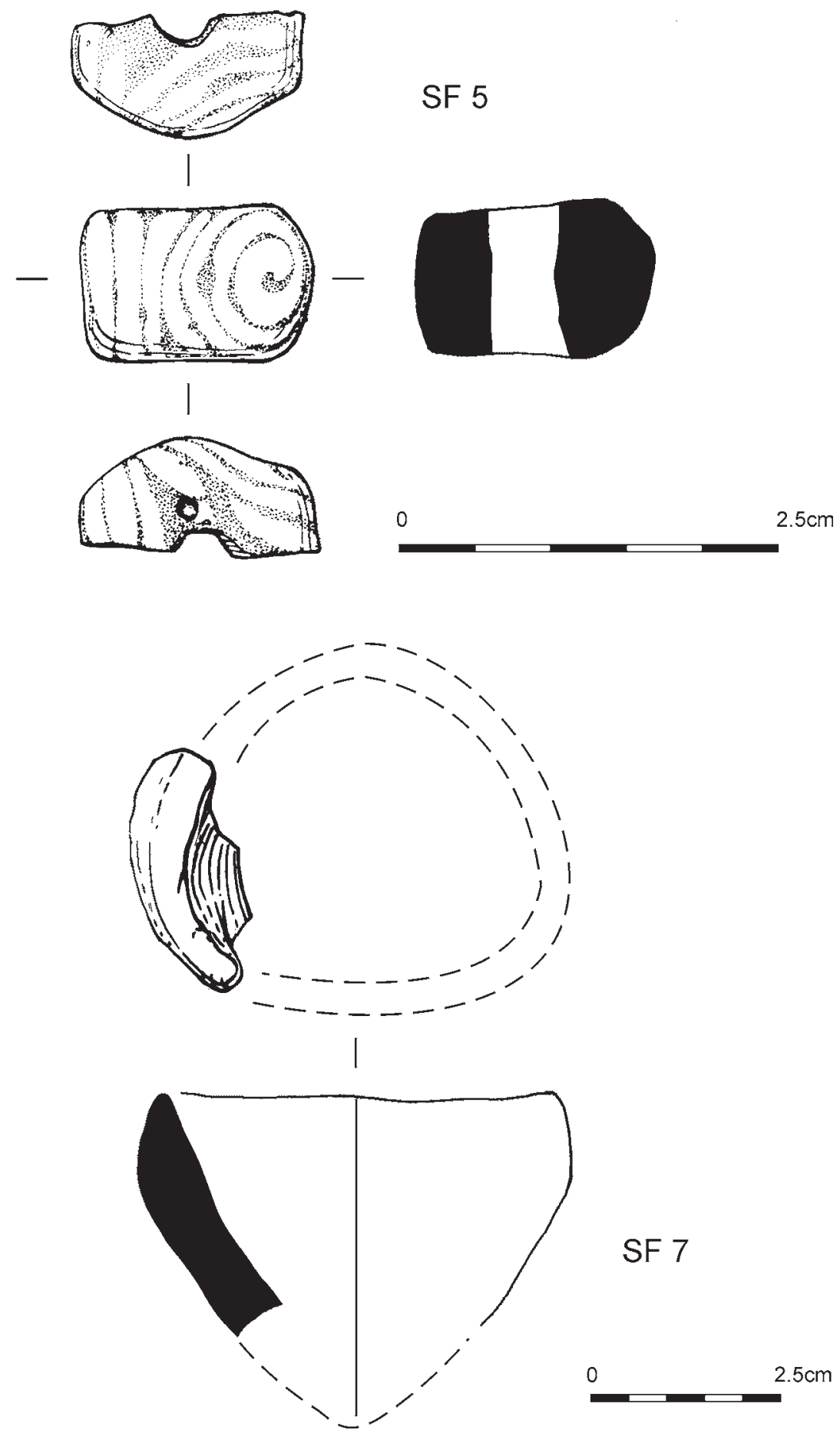

Illus 10 Glass bead (SF 5) and crucible (SF 7)

fication was carried out in the form of pressure-flaking. Overhanging edge-areas indicate that the scraper was used and re-sharpened. Context: north end of Trench 9 in topsoil (illus 12).

SF 2 Thumbnail side/end-scraper on primary bipolar flake, fine-grained honey-brown flint $(26 \times 22 \times 7 \mathrm{~mm})$. SF 2 is an approximately oval flake with a typical bipolar crushed terminal at the proximal end. At the distal end it has a convex, acute scraper-edge $\left(55^{\circ}\right)$, and along the right lateral side it has a slightly convex to straight, steep scraper-edge $\left(88^{\circ}\right)$. In the present case, the difference in steepness between the two working-edges is most likely the result of more or less extensive use. Most likely, the modification was carried out in the form of pressure- flaking. Context: c 40m south-east of roundhouse, found in topsoil during watching brief prior to excavation (illus 12).

SF 3 Secondary hard-hammer flake with edge-retouch, medium-grained brown flint $(39 \times 29 \times 9 \mathrm{~mm})$. The coarse convex retouch is located at the distal end of the right lateral side. A short segment (c 8-10 mm) of the right lateral side, and of the retouch, may have broken off, as well as the outermost distal tip of the piece. The retouch possibly represents the working-edge of an expedient scraper. Context: Feature 054 (illus 12).

SF 4 Distal fragment of secondary indeterminate flake with sporadic fine retouch or use-wear, medium-grained light olive-green flint $(22 \times 22 \times 8 \mathrm{~mm})$. The edge-modifi- 


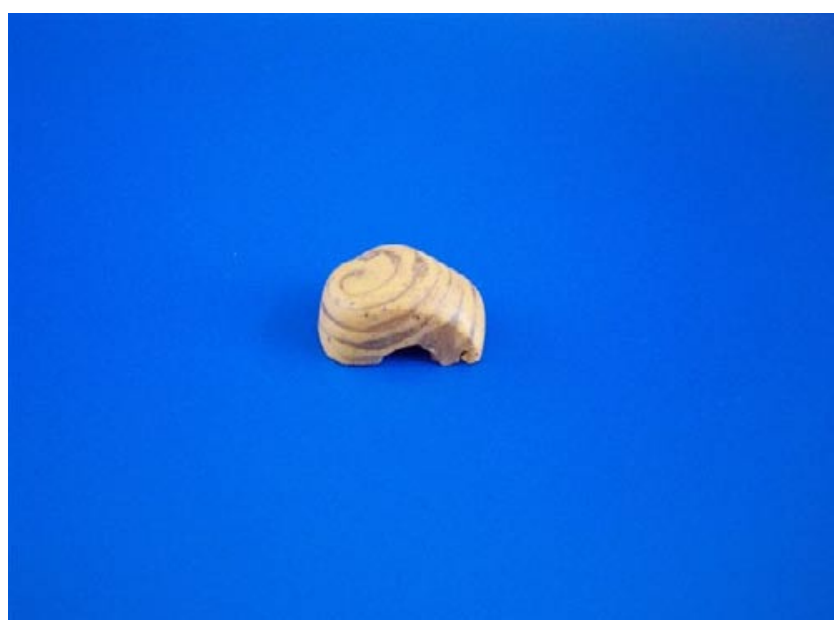

Illus 11 Glass bead (SF 5)
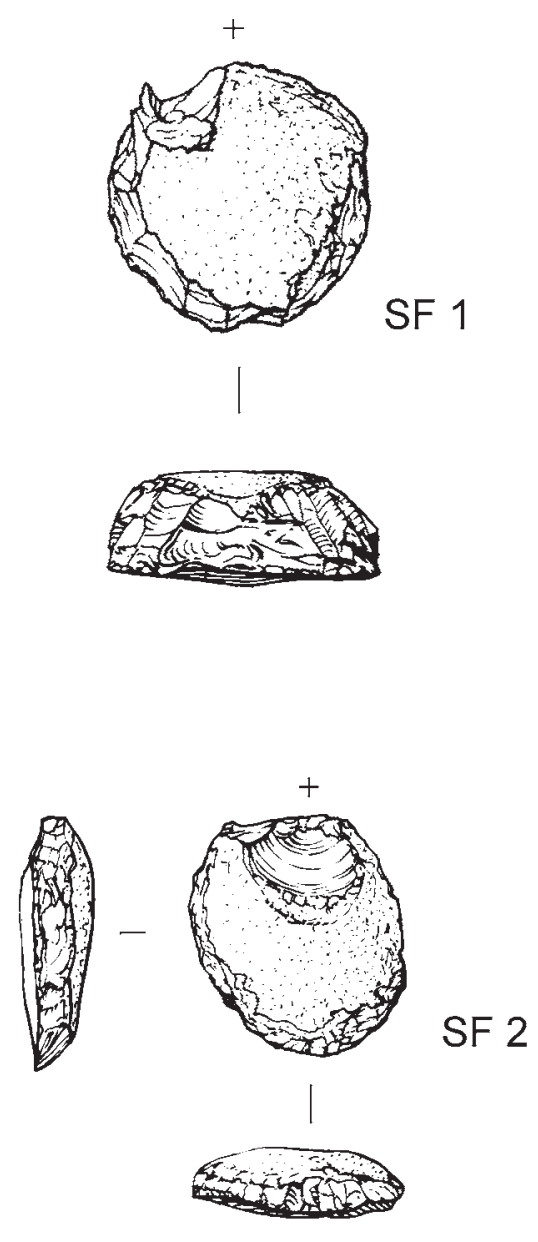

0 $2.5 \mathrm{~cm}$ cation is along the right lateral side. Context: by Feature 055 , surface (illus 12 ).

SF 6 Tertiary bipolar flake with use-wear, fine-grained cream-coloured flint $(12 \times 19 \times 5 \mathrm{~mm})$. This piece has an extremely irregular shape, and the operational schema responsible for the production of CAT 5 was highly unsystematic. Macroscopic use-wear at a distal corner suggests work in a graving/shaving fashion, and the piece may be an expedient tool. Context: Feature 056 (illus 12).

The five lithic objects most probably represent different prehistoric periods, with the two regular thumbnail scrapers dating to the Early Bronze Age, and the remaining expedient pieces to a later period. Based on typo-technological attributes, it is only possible to suggest a date of the Later Bronze Age or Early Iron Age for these pieces, as precise technological profiles have not yet been produced for potential Iron Age assemblages. There is some disagreement in the specialist community (eg Saville 1981a; Saville 1981b; Ford et al 1984; Herne 1991; Young \& Humphrey 1999; Humphrey \& Young 2003;

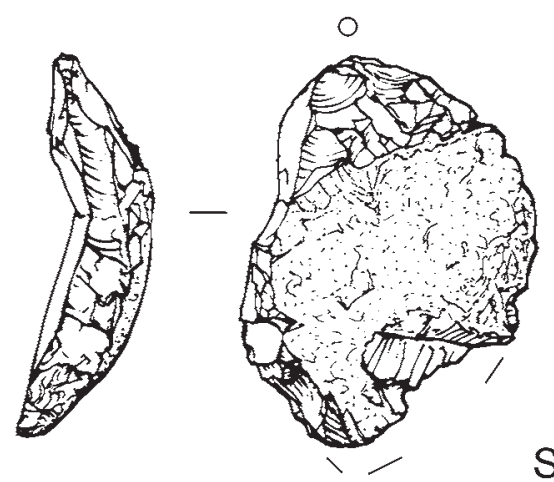

SF 3

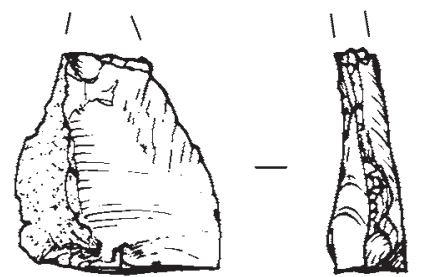

$+$
SF 4

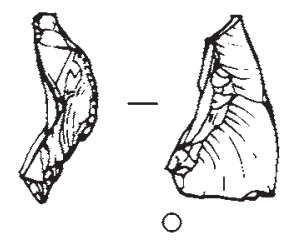

Illus 12 Lithic artefacts (SF 1, 2, 3, 4 \& 6) 
Martingell 2003) as to when '... regular production and use of flint artefacts for everyday domestic activities declined and ceased...' (Saville 1981b, 6). Unfortunately, the typo-technological attributes associated with possible Iron Age industries (eg Young \& Humphrey 1999, 232; Humphrey \& Young 2003, 87) fit Later Bronze Age industries just as well (eg Ballin 2002), and more work needs to be carried out to refine the presently too coarse technological profiles of potential Iron Age assemblages.

A number of assemblages from the Scottish quartz province (the north and west of the country) indicate that, at least in this area, lithic production continued well into the Iron Age - eg Jarlshof (Hamilton 1956, 39); Kebister (Clarke 1999, 164; Owen \& Lowe 1999, 148); Burland (Ballin 2003). As suggested by Herne, the final abandonment of regular flint or quartz use may have occurred at different times in different regions according to the relative availability of lithic raw materials and metal (Herne 1991, 73).

In the present situation, a possible Iron Age date is suggested by the distribution of lithic artefacts throughout the main building. Though finds from post-holes frequently pre-date the structure their posts are supporting, the recovery of flints from the site's pits only (or, in the case of SF 4, the immediate surroundings of an almost destroyed pit) suggests a connection between those pieces and the building and thereby a possible Iron Age date. However, even if an Iron Age date is accepted for these finds, it does not solve the general dispute, as three flints may just as well represent $a d$ hoc production as '... regular production and use ...'. 


\section{Discussion}

The physical location of the site suggests an area of some potential importance during the Iron Age. This is supported by the presence of an enclosed settlement or fort (Bruce's Camp named after a supposed medieval re-use) on the summit of the area of high ground, at Hill of Crichie, approximately $1 \mathrm{~km}$ north-west of the Thainstone site. This has currently not been excavated but may have been in use during the Iron Age.

A late 19th-century find of an Iron Age hoard on the Hill of Crichie in the vicinity of Bruce's Camp (exact findspot not recorded) also emphasizes the importance of the area in the period (Hunter 1997, 126). The hoard consisted of a bronze terret, a bronze ferrule for the butt of a spear shaft and 13 shale globular pinheads which had originally had iron pin shafts. The objects were found together 'under a large stone'. These are very high status objects, dating from the early centuries AD (Ralston \& Inglis $1984,57-8)$, the terrets often being regarded as of local manufacture.
In this context, the presence of the glass bead, and of the crucible fragment and its implication of bronzeworking on the site, suggest that, in the firstsecond centuries $\mathrm{AD}$, the Thainstone site was either itself part of a settlement of some status, or perhaps related or peripheral to a high status settlement. The reconstructed diameter of the roundhouse would be in accordance with such an interpretation. However, due to the intensive cultivation of the field, it is impossible to know if there had originally been other buildings nearby, or if this was an isolated building, possibly related to a settlement higher on the Hill of Crichie.

In light of the evidence of peaceful Roman interaction with the natives of the high status Iron Age native site of Birnie, Morayshire (Hunter 2002b), it is intriguing to speculate that the Thainstone site may possibly have been another settlement which continued in existence alongside the Roman presence. 


\section{Acknowledgements}

The excavators are grateful to ANM Group Ltd for their support and help throughout and for funding the excavation and post-excavation work. We are also grateful to Ian Shepherd and Moira Greig, Aberdeenshire Council Archaeology Service, for their advice and help. Thanks are also due to Murray Cook, AOC, and Fraser Hunter, National Museums of Scotland, for generously sharing the results of their excavations prior to publication. The finds have been illustrated by Jan Dunbar.

The project archive is deposited with the National Monuments Record of Scotland. The environmental report and wood identifications were undertaken by M Hastie, Headland Archaeology, and are deposited with the site archive at NMRS. 


\section{References}

Ballin, T B 2002 'Later Bronze Age flint technology: a presentation and discussion of post-barrow debitage from monuments in the Raunds area, Northamptonshire', Lithics 23, 3-28.

Ballin, T B 2003 The Quartz Assemblage from Burland on Trondra, Shetland. Unpublished report.

Breeze, D J 1996 Roman Scotland. Batsford/Historic Scotland, London.

Clark, J G D 1936 'Report on a Late Bronze Age site in Mildenhall Fen, West Suffolk', Antiquaries $J$ $16,29-50$.

Clarke, A 1999 'The flaked quartz', in Owen, O \& Lowe, C (eds) Kebister. The-Four-Thousand-YearOld Story of One Shetland Township, 164-6. Edinburgh ( = Soc Antiq Scot monogr ser 14).

DES 2000 Discovery and Excavation in Scotland. Council for Scottish Archaeology, Edinburgh.

Donnahue, RE \& Burroni, D B 2004'Lithic microwear analysis and the formation of archaeological assemblages', in Walker, E A, Wenban-Smith, F \& Healy, F (eds) Lithics in Action. Papers from the Conference Lithic Studies in the Year 2000. Lithic Studies Society Occasional Paper 8, 140 8. Oxbow Books, Oxford.

Ford, S et al. 1984 'Flint-working in the metal age', Oxford J Archaeol 3, 157-73.

Gent, H 1983 'Centralized storage in Later Prehistoric Britain', Proc Prehist Soc, 49, 243-67.

Green, H S 1980 The Flint Arrowheads of the British Isles. A Detailed Study of Material from England and Wales with Comparanda from Scotland and Ireland. Part i-ii. Oxford (= Br Archaol Rep, Br Ser 75).

Grieg, S 1940 Viking Antiquities in Great Britain and Ireland. Aschehoug, Oslo.

Guido, M 1978 The Glass Beads of the Prehistoric and Roman Periods in Britain and Ireland. London (= Soc Antiq Res Rep 35).

Hamilton, J R C 1956 Excavations at Jarlshof, Shetland. Ministry of Works, Archaeological Reports I. HMSO, Edinburgh.

Harding, D W \& Dixon, T N 2000 Dun Bharabhat, Cnip: an Iron Age Settlement in West Lewis. Volume 1: Structures and Material Culture. Dept of Archaeology, University of Edinburgh, Edinburgh.

Hastie, M 2005 Assessment of a Sample and Wood Charcoal from Thainstone Business Park, Inverurie, Aberdeenshire. Archive report.

Henderson, J 1994 'The glass', in Ballin Smith, B Howe: Four Millennia of Orkney Prehistory, 2346. Edinburgh ( = Soc Antiq Scot monogr ser 9).

Herne, A 1991 'The flint assemblage', in Longworth, I et al. Excavations at Grimes Graves, Norfolk
1972-1976. Fascicule 3, Shaft X: Bronze Age Flint, Chalk and Metal Working, 21-93. British Museum Press, London.

Hill, P H 1984 'A sense of proportion: a contribution to the study of double-ring round-houses', Scottish Archaeol Rev 3(2), 80-6.

Humphrey, J \& Young, R 2003 'Flint use in Later Bronze Age and Iron Age England? Some criteria for future research', in Moloney, N \& Shott, M J (eds) Lithic Analysis at the Millennium, 79-89. Institute of Archaeology, University College London, London.

Hunter, F 1997 'Iron Age hoarding in Scotland and northern England', in Gwilt, A \& Haselgrove, C (eds) Reconstructing Iron Age Societies, 108-33. Oxford (= Oxbow monogr 71).

Hunter, F 2002a Excavations at Birnie, Moray, 2001. National Museums of Scotland, Edinburgh.

Hunter, F 2002b 'Birnie: buying peace on the northern frontier', Curr Archaeol 181, 12-16.

Hunter, F 2003 Excavations at Birnie, Moray, 2002, Interim Publication, National Museums of Scotland, Edinburgh.

Keeley, L H 1980 Experimental Determination of Stone Tool Uses. A Microwear Analysis. University of Chicago, Chicago.

Laing, L R 1974 'Picts, Saxons and Celtic metalwork', Proc Soc Antiq Scot 105 (1972-4), 189-99.

Marshall, P et al. 1999 The Late Bronze Age and Early Iron Age Community at Cladh Hallan, South Uist. Interim publication. Sheffield Academic Press, Sheffield.

Martingell, H E 2003 'Later prehistoric and historic use of flint in England', in Moloney, N \& Shott, M J (eds) Lithic Analysis at the Millennium, 917. Institute of Archaeology, University College London, London.

Murray, H K in preparation Report on Reconstruction Research in Progress at Hill of Belnagoak, Methlick, Aberdeenshire.

Murray, J C 2002 Thainstone, Inverurie, Aberdeenshire: Archaeological Field Evaluation. Archive report.

Murray, J C \& Murray, H K 2003 'Thainstone (Kintore parish). Iron Age roundhouse', Discovery Excav Scot (New Ser) 4, 20.

Oswald, A 1997 'A doorway on the past: practical and mystic concerns in the orientation of roundhouse doorways', in Gwilt, A \& Haselgrove, C (eds) Reconstructing Iron Age Societies, 87-95. Oxford (= Oxbow monogr 71).

Owen, O \& Lowe, C (eds) 1999 Kebister. The-FourThousand-Year-Old Story of One Shetland Township. Edinburgh (= Soc Antiq Scot monogr ser 14). 
Parker Pearson, M \& Sharples, N 1999 Between Land and Sea:Excavations at Dun Vulan, South Uist. Sheffield Academic Press, Sheffield.

Pope, R 2003 Prehistoric Dwelling: Circular structures in North and Central Britain c 2500 $B C-A D$ 500. Unpublished $\mathrm{PhD}$ thesis, University of Durham, Durham.

Ralston, I \& Inglis, J 1984 Foul Hordes:The Picts in the North-East and Their Background. University of Aberdeen, Aberdeen.

Rideout, J S 1996 'Excavation of a promontory fort and a palisaded homestead at Lower Greenyards, Bannockburn, Stirling, 1982-5', Proc Soc Antiq Scot 126, 199-269.
Saville, A 1981a Grimes Graves, Norfolk. Excavations 1971 / 72: Volume II. The Flint Assemblage. Dept Environment Archaeol Rep 11. HMSO, London.

Saville, A 1981b 'Iron Age flintworking - fact or fiction?', Lithics 1, 6-9.

Shepherd, I A G 1986 Grampian. HMSO, Edinburgh.

Young, R \& Humphrey, J 1999 'Flint use in England after the Bronze Age: time for a re-evaluation?', Proc Prehist Soc 65, 231-42. 